\title{
Correlation between Serum Anti-Apoptotic Bcl-2 Level and its Immunohistochemical Expression in Relation to Apoptosis in Gastric Cancer
}

\author{
Sameer H. Fatani ${ }^{1}$, Mohammed H. Mukhtar ${ }^{1}$, Abeer S. Ali ${ }^{2}$, Hoda M. El-Emshaty ${ }^{3}$ and Wesam A. Nasif ${ }^{1 *}$ \\ ${ }^{1}$ Biochemistry Department, Faculty of Medicine, Umm Al-Qura University, Makkah, Saudi Arabia \\ ${ }^{2}$ Pathology Department, Faculty of Medicine, Umm Al-Qura University, Makkah, Saudi Arabia \\ ${ }^{3}$ Gastroenterology Center, Faculty of Medicine, Mansoura University, Mansoura, Egypt
}

\begin{abstract}
Introduction: Gastric cancer (GC) remains a major public health problem worldwide being the third commonest cause of cancer death worldwide. Many recent studies focus on the immunohistochemical evaluation of Bcl-2 expression and its serum expression and its prognostic significance in gastric cancer each one separately. We conducted our study to determine the correlation between serum Bcl-2 antigen and gastric carcinoma, to investigate whether serum Bcl-2 concentrations can be used as marker for immunohistochemical determination of $\mathrm{Bcl}-2$ alterations in gastric cancer patients and examine the association between its expression and other clinicopathological parameters.

Methods: Our study conducted in Forty-five consecutive patients with gastric cancer underwent gastrectomy in Mansoura Gastroenterology Center. ELISA was used for the estimation of serum Bcl-2 levels in patients with different stages of gastric cancer. Immunohistochemical localization of $\mathrm{Bcl}-2$ antigen was performed on formalinfixed, paraffin-embedded tissue block; Bcl-2 expression was detected from mild to moderate apoptotic index (Al).

Results: Positive serum Bcl-2 expression was found in $13 / 45$ patients (28.9\%). Bcl-2 protein was immunohistochemically localized in the cytoplasm of $45 \%$ (18/40) of gastric cancer patients. Total apoptosis positivity in $\mathrm{Bcl} 2$ detected immunohistochemicaly was detected in $45 \%$ (18/40) of cases; while total apoptosis positivity in serum expression of $\mathrm{Bcl}-2$ was detected in $28.9 \%$ (13/ 45).

Conclusion: our current study demonstrated that the formation and growth of cancer is a complex process that requires further research in correlation with the results assessed between serum and immunohistochemical expression of Bcl-2 and with its role in the process of apoptosis.
\end{abstract}

Keywords: Bcl-2; Apoptosis; Gastric cancer, Serum Bcl-2; Immunohistochemistry

\section{Introduction}

Gastric cancer (GC) remains a major public health problem worldwide being the third commonest cause of cancer death worldwide, with almost three quarters of a million deaths annually [1]. Several different types of cancer can arise in the stomach, including adenocarcinoma, lymphoma and leiomyosarcoma, but adenocarcinoma is by far the most common. Two types of gastric adenocarcinoma [intestinal-type and diffuse-type] can be differentiated histologically [2]. The proliferative activity and the apoptosis of premalignant and neoplastic tissue have been studied extensively.

Apoptotic disorders underlie carcinogenesis. The antiapoptotic $\mathrm{Bcl}-2$ has a major role in gastric cancer $[3,4]$. The assessment of its expression in gastric cancer cells in relation to morphological and histological factors help elucidate the formation and growth of various forms of gastric cancer. Apoptosis is a physiological programmed cell death that plays a major role in the process of carcinogenesis. It is known as one of the most important systems which control the number of cells in tissues [2]. Apoptosis is regulated by a variety of genes including p53 and Bcl-2 which may play an important role to keep the homeostasis of tissue dynamics [5-9].

Bcl-2 is defined as a new class proto-oncogene and can block cell death without affecting proliferation [10]. The anti-apoptotic Bcl-2 Family plays a pivotal role in the protection against DNA damage-induced apoptosis [11]. The expression of Bcl-2 has been associated with many human cancers; including gastric cancer. The presence of $\mathrm{Bcl}-2$ in cancer patients may be associated with poor prognosis and metastasis $[12,13]$.

Bcl-2 expression in cancer tissue is mainly assessed indirectly by immunohistochemistry. Immunohistochemical determination of Bcl-2 has been found to correlate with apoptotic activity in cancer tissue [2,3], however its detection necessitates the availability of cancer tissue from a surgical specimen or biopsy, is subject to the methodology used for the preparation of specimens and interpretation of findings $[4,9]$, and cannot be easily performed serially as the disease progresses with formation of metastases. However, despite its limitations, Bcl-2 immunohistochemistry represents a useful prognostic factor $[5,6]$, in selected categories of patients with colorectal cancer (CRC) $[7,14]$.

Bcl-2 can be measured by enzyme linked immunosorbent assay in serum samples from patients with gastric carcinoma and significantly raised compared with negative controls. Although tissue Bcl-2

*Corresponding author: Wesam A. Nasif, Biochemistry Department, Faculty of Medicine, Umm Al-Qura University, Makkah, Saudi Arabia, Tel: 00966566526609; E-mail:wnasif2003@yahoo.com, wanasif@uqu.edue.sa

Received August 24, 2015; Accepted October 02, 2015; Published October 04, 2015

Citation: Fatani SH, Mukhtar MH, Ali AS, El-Emshaty HM, Nasif WA (2015) Correlation between Serum Anti-Apoptotic Bcl-2 Level and its Immunohistochemical Expression in Relation to Apoptosis in Gastric Cancer. J Mol Biomark Diagn 6: 248. doi:10.4172/2155-9929.1000248

Copyright: @ 2015 Fatany SH, et al. This is an open-access article distributed under the terms of the Creative Commons Attribution License, which permits unrestricted use, distribution, and reproduction in any medium, provided the original author and source are credited 
Citation: Fatani SH, Mukhtar MH, Ali AS, El-Emshaty HM, Nasif WA (2015) Correlation between Serum Anti-Apoptotic Bcl-2 Level and its Immunohistochemical Expression in Relation to Apoptosis in Gastric Cancer. J Mol Biomark Diagn 6: 248. doi:10.4172/2155-9929.1000248

Page 2 of 6

estimation is a well-established procedure and its association with the invasiveness of the tumor and prognosis has been widely studied, serum Bcl-2 estimation has not been studied adequately.

We conducted this study to determine the correlation between serum Bcl-2 antigen and gastric carcinoma, and to investigate whether serum Bcl-2 protein concentrations can be used as marker for immunohistochemical determination of Bcl-2 alterations.

\section{Material and Methods}

\section{Tumor samples}

Forty-five consecutive patients with gastric cancer (29 males and 16 females) underwent gastrectomy in the Gastroenterology Center, Mansoura University, Mansoura, Egypt. The study was conducted in collaboration with the faculty of Medicine, Umm Al Qura University, Mekah city. The youngest patient was $20 \mathrm{yr}$ old, the oldest $76 \mathrm{yr}$, with median age of the series was $49.9 \pm 12.96$ years. A written consent was obtained from each patient included in the study to use the samples and clinical data for research purposes after being informed about the nature of the study. The study protocol conforms to the most recent ethical guidelines of the Declaration of Helsinki as reflected in a priori approval by local ethical committee. It was carried out during surgical resections for patients with gastric carcinoma either epithelial, stromal or even NHL underwent a potentially curative total or partial gastrectomy. All the information was reviewed such as age, sex, tumor location, tumor size, histological proliferation, clinical stage, depth of invasion, and metastasis. The current study was pursued on those patients prior to treatment including neo-adjuvant, radiotherapy and/ or chemotherapy. Negative controls were obtained from fifteen of normal serum and gastric mucosa samples. Tissue specimens were stored at $-70^{\circ} \mathrm{C}$ until used histologically diagnosed by the microscopic examination of hematoxylin and eosin stained sections.

\section{Measurement of serum Bcl-2 antigen in serum gastric cancer patients using ELISA}

Serum concentrations of the Bcl-2 protein were analyzed by Bcl-2 ELISA assay kit provided by oncogene research products (Oncogene Science, Cambridge, UK). The Bcl-2 ELISA is a "sandwich" enzyme immunoassay employing mouse monoclonal antibodies. Briefly, microtiter wells were precoated with mouse monoclonal antibodies specific for most native mammalian mutant Bcl-2 protein. Aliquots (50 $\mu \mathrm{L}$ ) of serum sample were added to each well, and were incubated at room temperature for 2 hours. After washing the wells, $100 \mu \mathrm{L}$ FITC conjugated detector monoclonal antibody were pipetted into each well, covered with a plate sealer and were incubated at room temperature for 30 minutes. After washing the wells, $100 \mathrm{~mL}$ horseradish peroxidaseconjugated anti-FITC antibody was added to each well, and was incubated in the dark at room temperature for 1 hour. After washing again, the wells were incubated with $100 \mathrm{~mL}$ chromogenic tetramethylbenzidine (TMB) from a colorless solution to a blue solution (or yellow after the addition of stopping reagent), the intensity of which is proportional to the amount of $\mathrm{Bcl}-2$ protein in the sample. The colored reaction product was quantified by examining its absorbance at $450 \mathrm{~nm}$ using a spectrophotometer.

The concentration of mutant $\mathrm{Bcl}-2$ protein in the serum was then determined by comparison against a standard curve generated from a known concentration of mutant Bcl-2 protein $(0 \mathrm{U} / \mathrm{ml}, 5.12 \mathrm{U} / \mathrm{ml}, 12.8 \mathrm{U} /$ $\mathrm{ml}, 32 \mathrm{U} / \mathrm{ml}, 80 \mathrm{U} / \mathrm{ml}$ and $200 \mathrm{U} / \mathrm{ml}$ ). By this approach, this assay can be seen to have a limit of detection of $5.12 \mathrm{U} / \mathrm{ml}$ and generate a linear standard curve up to $200 \mathrm{U} / \mathrm{ml}$, with cross reactivity with normal Bcl-2 according to the manufacturer (Oncogenic Science, Cambridge, UK).

\section{Immunohistochemistry}

Immunohistochemical localization of $\mathrm{Bcl}-2$ antigen was performed on formalin- fixed, paraffin-embedded tissue blocks that were cut on neoprene-coated slides. The immunostaining was performed using the avidin-biotin complex (ABC) method and an automatic autostainer (CODE-ON Immuno/DNA slide stainer; Biotek solution, Santa Barbara, CA). Slides were deparaffinized and blocked for endogenous peroxidase with $1.75 \%$ hydrogen peroxide in methanol for $20 \mathrm{~min}$. Antigen retrieval was performed for 15 min using Biogenex Antigen Retrieval Citra solution in $90^{\circ} \mathrm{C}$ water bath for $30 \mathrm{~min}$. The slides were allowed to cool for $20 \mathrm{~min}$ before continuing. Slides were then blocked by normal goat serum for $5 \mathrm{~min}$ at $37^{\circ} \mathrm{C}$. The monoclonal antibody was applied overnight in humid medium at room temperature followed by the biotinylated secondary antibody for $15 \mathrm{~min}$ at $37^{\circ} \mathrm{C}$ and the $\mathrm{ABC}$ complex for $15 \mathrm{~min}$ at $37^{\circ} \mathrm{C}$ (Vectastain Elite $\mathrm{ABC}$ Kit; Vector Laboratories, Burlingame, CA). Diaminobenzidine (DAB) was applied for $20 \mathrm{~min}$ at room temperature as chromogen, slides were counterstained with Mayer's hematoxylin, dehydrated, and covered by cover slips. In negative control slides, the same system was applied with replacement of the monoclonal antibody by diluted normal bovine serum. All slides were evaluated blindly without knowledge of the clinical outcome. Sections were considered positive if more than $5 \%$ of tumor cells were stained. Cytoplasmic immunostaining was scored for $\mathrm{Bcl}-2$ expression regarded as negative (score $=0$ ) and positive score $>0$ ) [5] that describes the diffuse and focal patterns of Bcl-2 immunoreactivity, considering the diffuse pattern representing the mutated $\mathrm{Bcl}-2$ protein and the focal one for the wild type Bcl-2 product.

\section{Apoptosis detection}

Apoptotic bodies were seen as single dark-stained roundish or pyknotic nuclear remnants, two or more nuclear fragments with uneven sizes and cytoplasmic eosinophilia located within or between adjacent tumor cells. Scores were given for each case based on the apoptotic bodies/HPF as follows: negative, 0 ; mild, 1-2; moderate, 3-5; and severe $>5$. Areas with much necrosis were excluded [6,7].

\section{Statistical analysis}

All statistical analyses were done using SPSS for Windows version 11.0 and statistical significance was indicated at a two-sided $p$ value $<0.05$. Numerical data were expressed as mean standard deviation (SD). The levels of markers were analyzed by analysis of variance. Correlations between serum $\mathrm{Bcl}-2$ protein marker and clinicopathological variables data were evaluated by Pearson's correlation coefficient. A p value $<0.05$ was considered significant.

\section{Results}

\section{Serum Bcl-2 protein}

The expression of $\mathrm{Bcl}-2$ was frequent in gastric cancer patients (40.6 to 86.6 units $/ \mathrm{ml}$, with average $51.3 \pm 9.2$ units $/ \mathrm{ml}$ ) compared with those in healthy blood donors as a negative control, $44.9 \pm 4.2 \mathrm{unit} / \mathrm{ml}$ $(p=0.004)$. The cut off value for the serum Bcl-2 protein concentration in the stomach cancer cases was defined as $53.4 \mathrm{unit} / \mathrm{ml}$. Therefore, serum Bcl-2 concentration above $53.4 \mathrm{unit} / \mathrm{ml}$ was defined as positive and those below as negative.

Positive serum Bcl-2 expression was found in 13/45 patients (28.9\%). The positive Bcl-2 protein was more frequently expressed in cancer cells in patients with gastric cancer $(61.6 \pm 10.9 \mathrm{unit} / \mathrm{ml})$ than in the negative group $(47.1 \pm 3.4 \mathrm{unit} / \mathrm{ml})$, the difference being statistically significant $(p<0.0001)$ (Figure 1). 
Citation: Fatani SH, Mukhtar MH, Ali AS, El-Emshaty HM, Nasif WA (2015) Correlation between Serum Anti-Apoptotic Bcl-2 Level and its Immunohistochemical Expression in Relation to Apoptosis in Gastric Cancer. J Mol Biomark Diagn 6: 248. doi:10.4172/2155-9929.1000248

Page 3 of 6

Clinicopathological parameters were assessed and correlated with serum Bcl-2 expression, and it was not significantly different with tumor type, patients' gender, age, tumor size, depth of invasion, stromal reaction and tumor site $(p>0.5)$ (Table 1$)$. Regardless of tumor stages, No statistically significant differences were observed in the positive expressions of Bcl-2 and tumor stages ( $p=0.78$ ), (Figure 2)

\section{Bcl-2 Immunostaining}

Bcl-2 expression was positive in 45\% (18 of 40) of in gastric cancer tissues and the rest of tumors (22 cases) were negative for $\mathrm{Bcl}-2$ immunostaining. Bcl-2 staining was observed in the cytoplasm and cytomembrane of carcinoma cells (Figure 3). The incidence of Bcl-2 immunostained cases was detected in $87.5 \%$ (7/8) of grade I, $35 \%(7 / 20)$ of grade II, and in $33.3 \%(4 / 12)$ of grade III $(P<0.02)$ (Table 2). Mean Bcl-2 concentrations were $54.13 \pm 13.52$ in

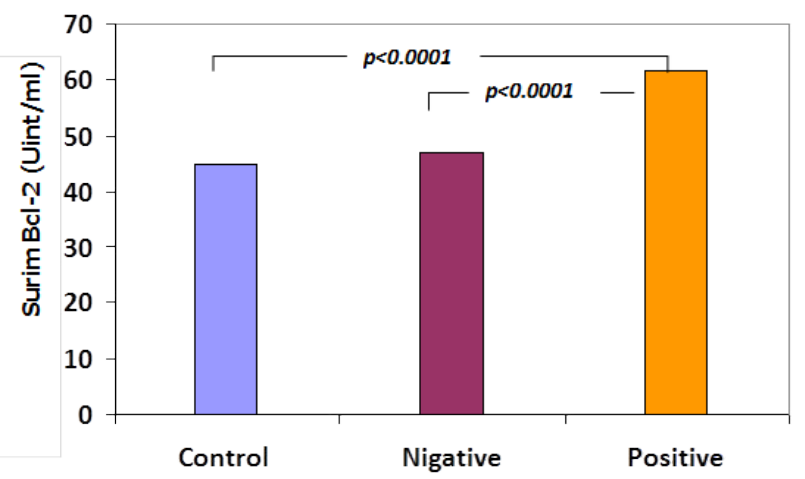

Figure 1: $\mathrm{Bcl}-2$ distribution in control and patients (negative and positive) cases. Positive serum Bcl-2 expression was found in $13 / 45$ patients $(28.9 \%)$. The positive Bcl-2 protein was more frequently expressed in cancer cells in patients with gastric cancer patients $(61.6 \pm 10.9 \mathrm{unit} / \mathrm{ml})$ than in the negative group $(47.1$ $\pm 3.4 \mathrm{unit} / \mathrm{ml})$, the difference being statistically significant $(p<0.0001)$.

\begin{tabular}{|c|c|c|c|c|}
\hline & \multicolumn{3}{|c|}{ Serum bcl-2 antigen (ELISA) } & \multirow[b]{2}{*}{ P. value } \\
\hline & $\begin{array}{c}\text { Total } \\
\text { No. }(\%)\end{array}$ & $\begin{array}{c}\text { Positive Bcl-2 } \\
\text { No.(\%) }\end{array}$ & $\begin{array}{c}\text { Negative Bcl-2 } \\
\text { No.(\%) }\end{array}$ & \\
\hline Mean Age \pm SD & $49.9 \pm 2.96$ & $48.5 \pm 12.8$ & $50.6 \pm 13.4$ & 0.88 \\
\hline \multicolumn{4}{|l|}{ Sex } & \multirow{3}{*}{0.1} \\
\hline Male & $29(64.4 \%)$ & $6(20.7 \%)$ & $23(79.3 \%)$ & \\
\hline Female & $16(35.6 \%)$ & $7 \quad(43.7 \%)$ & $9 \quad(56.3 \%)$ & \\
\hline \multicolumn{4}{|l|}{ Size } & \multirow{3}{*}{0.19} \\
\hline$<5$ & $17(37.8 \%)$ & $3(17.6 \%)$ & $14 \quad(82.4 \%)$ & \\
\hline$>5$ & $28(62.2 \%)$ & $10(35.7 \%)$ & $18(64.3 \%)$ & \\
\hline \multicolumn{4}{|l|}{ Site } & \multirow{4}{*}{0.17} \\
\hline Antrum & $25(55.6 \%)$ & $8 \quad(32.0 \%)$ & $17(68.0 \%)$ & \\
\hline Body & $13(28.9 \%)$ & $4 \quad(30.8 \%)$ & $9 \quad(69.2 \%)$ & \\
\hline Cardia & $7 \quad(15.6 \%)$ & $1(14.3 \%)$ & $6 \quad(85.7 \%)$ & \\
\hline \multicolumn{4}{|l|}{ Gross (shape) } & \multirow{4}{*}{0.19} \\
\hline Ulcerating & $27(60.0 \%)$ & $8 \quad(32.0 \%)$ & $19(70.4 \%)$ & \\
\hline Infiltrating & $9 \quad(20.0 \%)$ & $4 \quad(30.8 \%)$ & $8 \quad(88.9 \%)$ & \\
\hline Polypoi & $9 \quad(20.0 \%)$ & $1(14.3 \%)$ & $5 \quad(55.6 \%)$ & \\
\hline \multicolumn{4}{|l|}{ Type } & \multirow{4}{*}{0.8} \\
\hline Epithelial tumor & $37(82.2 \%)$ & $8 \quad(29.6 \%)$ & $27 \quad(73.0 \%)$ & \\
\hline Stromal tumor & $3(06.7 \%)$ & $1 \quad(11.1 \%)$ & $1 \quad(33.3 \%)$ & \\
\hline $\mathrm{NHL}$ & $5 \quad(11.1 \%)$ & $4 \quad(44.4 \%)$ & $4 \quad(40.0 \%)$ & \\
\hline \multicolumn{4}{|l|}{ Grade } & \multirow{4}{*}{0.12} \\
\hline Low & $10(22.2 \%)$ & $3 \quad(30.0 \%)$ & $7 \quad(70.0 \%)$ & \\
\hline Intermediate & $23(51.1 \%)$ & $4 \quad(17.4 \%)$ & $19(82.6 \%)$ & \\
\hline High & $12(26.7 \%)$ & $6 \quad(50.0 \%)$ & $6 \quad(50.0 \%)$ & \\
\hline Total & $45(100 \%)$ & $13(28.9 \%)$ & $32(71.1 \%)$ & \\
\hline
\end{tabular}

Table 1: Clinicopathological parameters against serum Bcl-2 antigen by ELSIA.

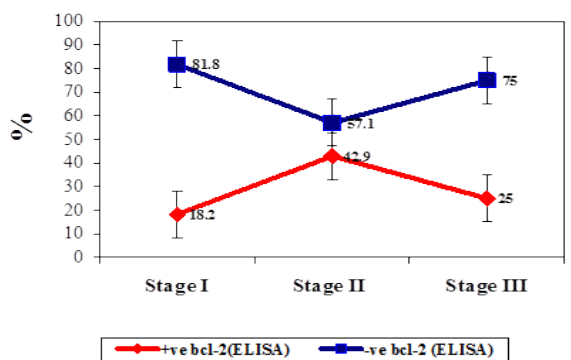

Figure 2: Correlation between tumor stage with frequency of Serum Bcl-2 protein by ELISA.

\begin{tabular}{|c|c|c|c|c|}
\hline & \multicolumn{4}{|c|}{ bcl-2 expression (I.H) } \\
\hline & $\begin{array}{c}\text { Total } \\
\text { No. }(\%)\end{array}$ & $\begin{array}{c}\text { Positive bcl-2 } \\
\text { No. }(\%)\end{array}$ & $\begin{array}{c}\text { Negative bcl-2 } \\
\text { No. }(\%)\end{array}$ & $P$ value \\
\hline Mean Age \pm SD & $50.7 \pm 13.2$ & $47.4 \pm 12.7$ & $53.2 \pm 13.2$ & 0.47 \\
\hline \multicolumn{4}{|l|}{ Sex } & \multirow{3}{*}{0.6} \\
\hline Male & $24(60.0 \%)$ & $10(41.7 \%)$ & $14(58.3 \%)$ & \\
\hline \multirow{2}{*}{\multicolumn{4}{|c|}{$\begin{array}{l}\text { Female } \\
\text { Size }\end{array}$}} & \\
\hline & & & & \multirow[t]{3}{*}{0.14} \\
\hline$<5$ & $13(32.5 \%)$ & $8 \quad(61.5 \%)$ & $5 \quad(38.5 \%)$ & \\
\hline$>5$ & $27(67.5 \%)$ & $10 \quad(37.0 \%)$ & $17(63.0 \%)$ & \\
\hline \multicolumn{4}{|l|}{ Site } & \multirow[t]{4}{*}{0.31} \\
\hline Antrum & $22(55.0 \%)$ & $12(54.5 \%)$ & $10 \quad(45.5 \%)$ & \\
\hline Body & $13(32.5 \%)$ & $5 \quad(38.8 \%)$ & $8 \quad(61.5 \%)$ & \\
\hline Cardia & $5(12.5 \%)$ & $1(20.0 \%)$ & $4 \quad(80.0 \%)$ & \\
\hline \multicolumn{4}{|l|}{ Gross (shape) } & \multirow{4}{*}{0.5} \\
\hline Ulcerating & $22(55.0 \%)$ & $9 \quad(37.5 \%)$ & $15(62.5 \%)$ & \\
\hline Infiltrating & $7(17.5 \%)$ & $4 \quad(57.1 \%)$ & $3(42.5 \%)$ & \\
\hline Polypoid & $9(22.5 \%)$ & $5(55.6 \%)$ & $4 \quad(44.4 \%)$ & \\
\hline \multicolumn{4}{|l|}{ Type } & \multirow[t]{4}{*}{0.15} \\
\hline Epithelial tumor & $32(80.0 \%)$ & $12(37.5 \%)$ & $20 \quad(62.5 \%)$ & \\
\hline Stromal tumor & $3(07.5 \%)$ & $2(66.7 \%)$ & $1 \quad(33.3 \%)$ & \\
\hline $\mathrm{NHL}$ & $5(12.5 \%)$ & $4 \quad(80.0 \%)$ & $1(20.0 \%)$ & \\
\hline \multicolumn{4}{|l|}{ Grade } & \multirow[t]{4}{*}{0.026} \\
\hline Low & $8(20.0 \%)$ & $7 \quad(87.5 \%)$ & $1 \quad(12.5 \%)$ & \\
\hline Intermediate & $20(50.0 \%)$ & $7 \quad(35.0 \%)$ & $13(65.0 \%)$ & \\
\hline High & $12(30.0 \%)$ & $4 \quad(33.3 \%)$ & $8(66.7 \%)$ & \\
\hline Total & $40(100 \%)$ & $18(45.0 \%)$ & $22 \quad(55.0 \%)$ & \\
\hline
\end{tabular}

Table 2: Clinicopathological parameters against $\mathrm{Bcl}-2$ expression detected by immunohistochemical (I.H)

grade I; $49.2 \pm 4.7$ in grade II; and $55.5 \pm 11.36$ in grade III; showing a significant difference between grade II and III only $(P<0.03)$. There was no correlation between $\mathrm{Bcl}-2$ and other pathological parameters, such as age, gender, histological type, tumor location, or tumor size (Table 2). Also, there was no significant association between $\mathrm{Bcl}-2$ expression and tumor stage $(p=0.9)$ (Figure 4$)$.

\section{Correlation between serum Bcl-2 protein concentration} and immunostaining

The correlation between serum $\mathrm{Bcl}-2$ protein concentration and immunohistochemical staining for $\mathrm{Bcl}-2$ protein was analyzed in 40 matched cases of gastric cancer (Table 3). Positive serum Bcl-2 concentrations were found in $10(55.6 \%)$ of 18 positive immunostained cases, but in only three (13.6\%) of 22 negative immunostained cases $(p<0.002)$ (Figure 3). In addition, serum negative $\mathrm{Bcl}-2$ was found in $19(86.4 \%)$ of 22 cases negative for Bcl-2 protein by immunostaining (Table 3). Positive immunostaining for Bcl-2 protein was found in 10 
Citation: Fatani SH, Mukhtar MH, Ali AS, El-Emshaty HM, Nasif WA (2015) Correlation between Serum Anti-Apoptotic Bcl-2 Level and its Immunohistochemical Expression in Relation to Apoptosis in Gastric Cancer. J Mol Biomark Diagn 6: 248. doi:10.4172/2155-9929.1000248

(76.9\%) of 13 cases positive for Bcl-2 protein in serum and in $8(29.6 \%)$ of 27 cases negative for serum Bcl-2 antigen (Figure 4 and Table 3 ).

\section{Apoptotic index}

Expression of Bcl- 2 was increased stepwise from mild to moderate apoptotic index (AI) but negative expression was observed at severe AI. Total apoptosis positivity in Bcl-2 detected immunohistochemicaly was detected in $45 \%(18 / 40)$ of cases with gastric cancer; while total apoptosis positivity in serum expression of Bcl-2 was detected in $28.9 \%$ $(13 / 45)$ of cases with gastric cancer (Table 4). However, there is no significance between AI with clinicopathological variables.

\section{Discussion}

In addition to known conventional prognostic factors such as the depth of tumor invasion, the number of involved lymph nodes and the involvement of resection margins, a plethora of markers have been suggested as possible prognostic factors in patients with gastric cancer, including the apoptosis inhibitor $\mathrm{Bcl}-2$, tumor suppressor genes.

It is well established that apoptosis is deregulated during cancer development and progression. The anti-apoptosis $\mathrm{Bcl}-2$ protein was over-expressed in various malignancies at mRNA and protein levels $[15,16]$. In GC, previous studies have shown that expression of Bcl-2 gene suppresses the cellular proliferative activity and is correlated with less aggressive biological behavior [17-19].

In this study, we investigated the serum level and immunohistochemical expression of $\mathrm{Bcl}-2$ protein in 40 gastric

\begin{tabular}{|c|c|c|c|}
\hline & \multicolumn{3}{|c|}{ Bcl-2 immunostaining } \\
\cline { 2 - 4 } & $\begin{array}{c}\text { Negative Bcl-2 } \\
\text { No. }\end{array}$ & $\begin{array}{c}\text { Positive Bcl-2 } \\
\text { No. }\end{array}$ & $\begin{array}{c}\text { Total Bcl-2 } \\
\text { No. }\end{array}$ \\
\hline $\begin{array}{c}\text { SerumBcl-2 } \\
\text { protein }\end{array}$ & & & 27 \\
\hline Negative & 19 & 8 & 13 \\
\hline Positive & 3 & 10 & 40 \\
\hline Total & 22 & 18 & \\
\hline
\end{tabular}

Note: Positive serum Bcl-2 concentration were found in 10 of $18(55.6 \%)$ positive immunostaining cases, but in only 3 out of $22(13.6 \%)$ negative immunostaining.

Table 3: Correlation between serum $\mathrm{Bcl}-2$ protein concentration and immunostaining in 40 patients with gastric cancer

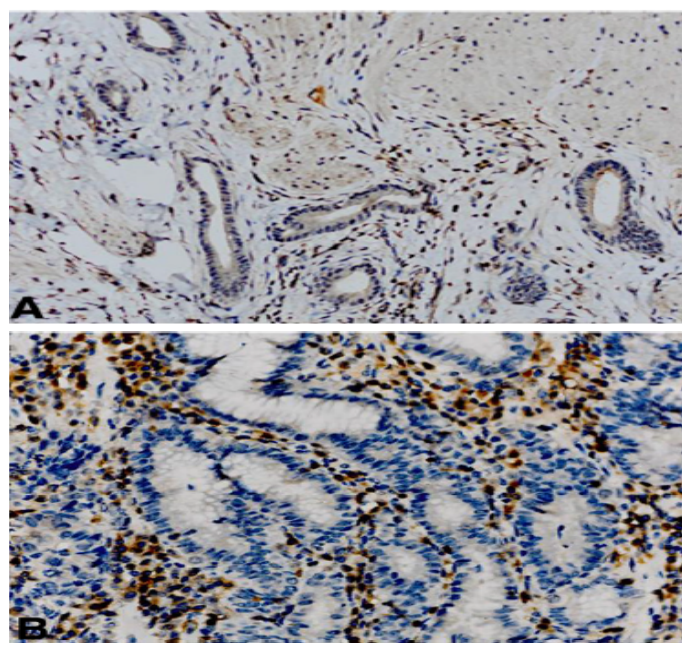

Figure 3: Immunohistochemical staining of $\mathrm{Bcl}-2$ using monoclonal antibody and avidin-biotin peroxidase detection in gastric cancer tissue showing intracytoplasmic immunoreactivity of $\mathrm{Bcl}-2$. A original magnification $\times 100, B$ original magnification $\times 400$.

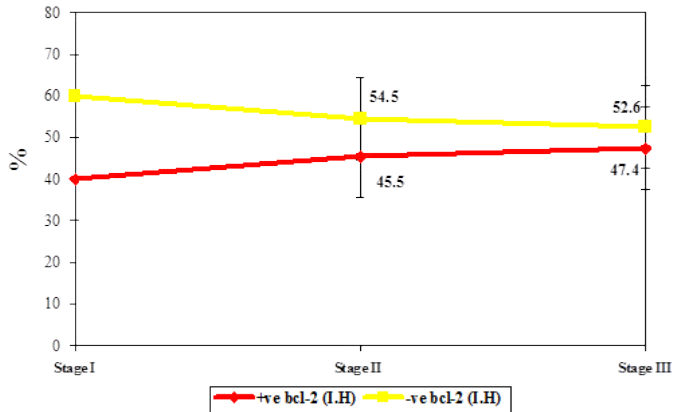

Figure 4: Correlation between tumor stages with frequency of $\mathrm{Bcl}-2$ by immunohistochemical (I.H)

\begin{tabular}{|c|c|c|c|c|c|}
\hline & $\begin{array}{l}\text { Negative } \\
\text { No.(\%) }\end{array}$ & $\begin{array}{c}\text { Mild } \\
\text { No.(\%) }\end{array}$ & $\begin{array}{l}\text { Moderate } \\
\text { No.(\%) }\end{array}$ & $\begin{array}{l}\text { Marked } \\
\text { No.(\%) }\end{array}$ & $P$ value \\
\hline \multicolumn{6}{|c|}{ Bcl-2 expression (I.H) } \\
\hline \multirow[t]{2}{*}{ Positive Bcl-2 } & \multirow{2}{*}{$\begin{array}{l}1(25.0 \%) \\
3(75.0 \%)\end{array}$} & $8(47.1 \%)$ & $9 \quad(47.4 \%)$ & $18 / 40 \quad(45.0 \%)$ & 0.69 \\
\hline & & $9(75.0 \%)$ & $10 \quad(52.6 \%)$ & $22 / 40 \quad(55.0 \%)$ & \\
\hline \multicolumn{6}{|c|}{ Serum bcl-2 antigen } \\
\hline Positive Bcl-2 & $\begin{array}{c}2 \\
(28.6 \%)\end{array}$ & $\begin{array}{c}4 \\
(22.2 \%)\end{array}$ & $7 \quad(35.0 \%)$ & $13 / 45 \quad(28.9 \%)$ & \\
\hline Negative Bcl-2 & $\begin{array}{c}5 \\
(71.4 \%)\end{array}$ & $\begin{array}{c}14 \\
(77.8 \%)\end{array}$ & $13(65.0 \%)$ & $32 / 45 \quad(71.1 \%)$ & 0.57 \\
\hline
\end{tabular}

Table 4: Correlation between Apoptotic index (Al) (negative, mild, moderate, marked) serum Bcl-2 protein expression in 45 patients and immunostaining in 40 patients with gastric cancer.

carcinomas and the results were compared with the clinicopathological data of these patients. Bcl-2 protein was detected by ELISA assay in the sera of $28.9 \%(13 / 45)$ of our patients. Mean serum concentration of $\mathrm{Bcl}-2$ positive was elevated significantly $(P<0.0001)$ in positive cases compared to negative ones. The expression of $\mathrm{Bcl}-2$ was reported to increase in cells of gastric cancer [20]. The expression of Bcl-2 is a phenomenon that occurs in the early period in the development of gastric cancer. These results are in agreement with Nasif et al., who reported that $\mathrm{Bcl}-2$ protein was detected by ELISA assay in the sera of $32.5 \%$ (13/40) [21]. Mean serum concentration of Bcl-2 positive was elevated significantly $(P<0.0001)$ in positive cases compared to negative ones. Also these results are coincident with those reported by Mohamed El-Shahat et al. who's stated that Bcl-2 expression is elevated in liver of cirrhotic patients and this increase may correlate with the development of HCC [22]. Also our results were agreed with other previous results of Athanassios et al. who reported that Bcl-2 protein was expressed in $67 \%$ of gastric adenocarcinomas examined [23]. The expression of $\mathrm{Bcl}-$ 2 is a phenomenon that occurs in the early period in the development of gastric cancer. Therefore, Bcl-2 might do some work both in the triggering of gastric cancer and developing of early gastric cancer [24].

According to tumor size; there was a significant negative correlation with the tumour size. These results are coincident with the results reported by LIU Hai-Feng, et al. and Jianghong Wu et al. reported that there was no significant relationship between $\mathrm{Bcl}-2$ protein expression and tumor size respectively $[25,26]$. But Silviastrini et al. found that Bcl-2 protein expression was related to the tumor size [27]. A significantly higher fraction of Bcl-2 positive cells was observed in small tumors than in large tumors. But these results was not confident with that reported by Jianghong $\mathrm{Wu}$ et al. who reported that There was no correlation between $\mathrm{Bcl}-2$ and other clinicopathological parameters, such as age, gender, histological type, tumor location, or tumor size [26]. 
Citation: Fatani SH, Mukhtar MH, Ali AS, El-Emshaty HM, Nasif WA (2015) Correlation between Serum Anti-Apoptotic Bcl-2 Level and its Immunohistochemical Expression in Relation to Apoptosis in Gastric Cancer. J Mol Biomark Diagn 6: 248. doi:10.4172/2155-9929.1000248

Page 5 of 6

Positive staining for Bcl-2 expression was detected in $45 \%$ (18 of 40 ) of gastric cancer tissue. This proportion is similar to that in other studies as that reported in previous studies by Saegusa et al. and Muller et al. was found in $12.6 \%(13 / 103)$ and $11.4 \%(47 / 413)$ of cases, respectively $[24,28]$. These results was also comes coincident with that reported by Jianghong $\mathrm{Wu}$ et al. who found that Bcl-2 expression was positive in $21.2 \%$ of all gastric cancer tissues [26]. Bcl-2 staining was observed in the cytoplasm and cytomembrane of carcinoma cells.

A Significant correlation was detected between positive Bcl-2 and tumor grade $(p<0.026)$. This is coordinated with the results of Dorra Ben Ayed et al. and Ben Ayed-Guerfali et al. who reported that there was a significant association between $\mathrm{Bcl}-2$ expression and grade of tumor [29,30]. Also this result is agreed with Lukyanova et al. who reported that Bcl-2 is differently expressed in epithelial ovarian carcinoma varying by histological grade as well as biological features which could be useful for both prognosis and therapy correction [31]. But there was no significant association between Bcl-2 expression and tumor stage $(p=0.9)$.

One characteristic feature of cancer is continuous growth. An important feature to assess the clinical behavior of tumors is to assess the balance between the proliferative activities and the apoptosis processes [29]. The rates of cell proliferation and cell death may determine the speed of this growth [32]. The inability of cells to undergo apoptosis may advance cancer development, both by allowing dividing cells to accumulate and by not eliminating genetic mutants that may harbor enhanced malignant potential. Total apoptosis positivity in $\mathrm{Bcl}-2$ detected immunohistochemicaly was detected in $45 \%$ (18/40) of cases with gastric cancer, while total apoptosis positivity in serum expression of $\mathrm{Bcl}-2$ was detected in $28.9 \%$ (13/45) of cases with gastric cancer; the total negativity was recorded in $71.1 \%(32 / 45)$. Moderate to marked AI was detected in 9 (47.4\%). While moderate to marked expression was detected in 7 (35\%) of positive serum Bcl-2 expression. These results come coincident with the results previously reported by Athanassios et al. which revealed that none statistically significant correlation was found between Bcl-2 immunoreactivity and apoptotic body index and survival [23]. This indicates that the failure of the apoptotic process leads to an increase survival of cells with DNA damage. The mechanism may be involved in GC.

\section{Conclusion}

The positivity of Bcl-2 expression correlated with different groups of gastric cancer was studied in the current study. Immunohistochemical $\mathrm{Bcl}-2$ expression is suggested to have a possible prognostic value with serum $\mathrm{Bcl}-2$ expression on gastric cancer. In advanced-stage and highgrade gastric carcinomas indicates that $\mathrm{Bcl}-2$ is involved in early stage of tumor development and constitutes an independent prognostic factor regarding the outcome of patients with gastric cancer. The presented results demonstrated that the formation and growth of cancer is a complex process that requires further research in correlation with the results assessed between serum and immunohistochemical expression of Bcl-2 and with its role in the process of apoptosis.

\section{Acknowledgment}

We would like to thank Prof. Hanan Abd Al Monem, Department of Pathology, Faculty of Medicine, Umm Al Qurra University, Mekkah city, for having read the manuscript and for making useful suggestions.

\section{References}

1. Ferlay J, Soerjomataram I, Ervik M, Dikshit R, Eser S, et al. (2013) GLOBOCAN2012, version 1.0: Cancer incidence and mortality worldwide. IARC CancerBase No 11. International Agency for Research on Cancer; http:globocan.iarc.
2. Petros AM, Olejniczak ET, Fesik SW (2004) Structural biology of the Bcl-2family of proteins. Biochim Biophys Acta 1644: 83-94.

3. Ashktorab H, Dashwood RH, Dashwood MM (2008) H. pylori-induced apoptosis in human gastric cancer cells mediated via the release of apoptosis-inducing factor from mitochondria. Helicobacter 13: 506-517.

4. Zhang H, Fang DC, Lan CH, Luo YH (2007) Helicobacter pylori infection induces apoptosis in gastric cancer cells through the mitochondrial pathway. Journal of Gastroenterology and Hepatology 22: 1051-1056.

5. Agui T, McConkey DJ, Tanigawa N (2002) Comparative study of various biological parameters, including expression of surviving, between primary and metastatic human colonic adenocarcinomas. Anticancer Res 22: 1769-1776.

6. Guzinska-Ustimowicz K, Famulski W, Stasiak-Barmuta A, Zalewski B Sulkowska M, et al. (2002) Correlation between colorectal cancer Bcl-2 expression and tumour clinicopathological variables. Rocz Acad Med Bialymst 47: 246-253.

7. Sun $X F$, Bartik Z, Zhang $H$ (2003) Bcl-2 expression is a prognostic factor in the subgroups of patients with colorectal cancer. Int J Oncol 23: 1439-1443.

8. Manne U, Weiss $\mathrm{H}$, Grizzle W (2002) Bcl-2 expression is associated with improved prognosis in patients with distal colorectal carcinoma. Int $\mathrm{J}$ Cancer (Pred Oncol) 89: 423-430.

9. Pan W, Ishii H, Ebihara Y, Gobe G (2003) Prognostic use of growth characteristics of early gastric cancer and expression patterns of apoptotic, cell proliferation, and cell adhesion proteins. Journal of Surgical Oncology 82: 104- 110.

10. Korsmeyer S (1992) Bcl-2 initiates a new category of oncogenes: regulators of cell death. Blood 80: 879-886.

11. Simonin K, Brotin E, Dufort S, Dutoit S, Goux D, et al. (2009) Mcl-1 is an important determinant of the apoptotic response to the BH3-mimetic molecule HA14-1 in cisplatin-resistant ovar-ian carcinoma cells. Mol Cancer Ther 8 : 3162-3170.

12. de Vicente JC, Olay S, Lequerica-Fernandez $P$, Sánchez-Mayoral J, Junquera LM, et al. (2006) Expression of Bcl-2 but not Bax has aprognostic significance in tongue carcinoma. J Oral Pathol Med 35: 140-145.

13. Wyllie AH (1992) Apoptosis and the regulation of cell numbers in normal and neoplastic tissues: an overview. Cancer Metastasis Rev 11: 95-103.

14. Sun XF, Bartik Z, Zhang H (2003) Bcl-2 expression is a prognostic factor in the subgroups of patients with colorectal cancer. Int J Oncol 23: 1439-1443.

15. Lauwers GY, Scott GV, Karpeh MS (1995) Immunohistochemical evalu-ation of Bcl-2 protein expression in gastric adenocarcinomas. Cancer 75: 2209-13.

16. Krajewska M, Krajewski S, Epstein JI, Shabaik A, Sauvageot J, et al. (1996) Immunohistochemical analysis of bcl-2, bax, bcl-X, and mcL-1 expression in prostate cancers. Am J Pathol 148: 1567-76.

17. Aizawa K, Ueki K, Suzuki S, Yabusaki H, Kanda T, Nishimaki T, et al. (1999) Apoptosis and Bcl-2 expression in gastric carcinoma: correlationwith clinicopathological variables, p53 expression, cell prolifer-ation and prognosis. Int $\mathrm{J}$ Oncol 14: 85-91.

18. Zafirellis K, Karameris A, Milingos N, Androulakis G (2005) Molecular markers in gastric cancer: can p53 and bcl-2 protein expressions be used as prognostic factors?. Anticancer Res 25: 3629-3636.

19. Tsamandas AC, Kardamakis D, Tsiamalos P, Liava A, Tzelepi V, et al. (2009) The potential role of $\mathrm{Bcl}-2$ expression, apoptosis and cell proliferation (Ki67 expression) in cases of gastric carcinoma and correlation with classic prognostic factors and patient outcome. Anticancer Res 29: 703-709.

20. Sundblad AS, Tamayo R (1995) Expression of MIB-1/ki 67 and Bcl-2 in gastric carcinoma: Relationship with clinicopathological factors. Acta Gastoenterol Latin Am 25: 67-72.

21. Nasif WA, El-Emshaty HM, Lotfy M, Zalata K, El-Hak NG (2007) Apoptosis Dysregulation in Human Gastric Carcinomas: Relationship to Anti- and ProApoptotic Protein Expression. Asian Pacific J Cancer Prev 8: 45.

22. El-Shahat M, El-Masry S, Lotfy M, El-Meghawry A, El-Kenawy, et al. (2005) Relationship of Helicobacter pylori to Bcl-2 Family Expression, DNA Content, and Pathological Characteristics of Gastric Cancer. International Journal of Gastrointestinal Cancer 36: 61-68.

23. Tsamandas AC, Dimtrios K, Tsiamalos P, Liava A, Tzelep V, et al. (2009) 
Citation: Fatani SH, Mukhtar MH, Ali AS, El-Emshaty HM, Nasif WA (2015) Correlation between Serum Anti-Apoptotic Bcl-2 Level and its Immunohistochemical Expression in Relation to Apoptosis in Gastric Cancer. J Mol Biomark Diagn 6: 248. doi:10.4172/2155-9929.1000248

Page 6 of 6

The Potential Role of Bcl-2 Expression, Apoptosis and Cell Proliferation (Ki67 Expression) in Cases of Gastric Carcinoma and Correlation with Classic Prognostic Factors and Patient Outcome. Anticancer Research 29: 703-710.

24. Saegusa M, Takano Y, Okayasu I (1995) Bcl-2 expression and its association with cell kinetics in human gastric carcinomas and intestinal metaplasia. $J$ Cancer Res Clin Oncol 121: 357-63

25. LIU Hai-Feng, LIU Wei-Wen, FANG Dian-Chun, MEN Rong-Pu (1998) Expression of bcl-2 protein in gastric carcinoma and its significance. WJG 4: 228-230.

26. Wu J, Liu X, Cai H, Wang Y (2014) Prediction of tumor recurrence after curative resection in gastric carcinoma based on bcl-2 expression. World Journal of Surgical Oncology 12: 40

27. Silviastrini R, Veneroni S, Daidone MG, Benini E, Boracchi P, et al. (1994) The bcl-2 protein: a prognostic indicator strongly related to p53 protein in lymph- node negative breats cancer patients. J Natl Cancer Inst 86: 499-504.

28. Muller W, Schneiders A, Hommel G, Gabbert HE (1998) Prognostic value of bcl-2 expression in gastric cancer. Anticancer Res 18: 4699-4704.

29. Ayed DB, Khabir A, Abid M, Bayrouti MI, Gargouri A, et al. (2014) Clinicopathological and prognostic significance of p53, Ki-67, andBcl-2 expression in Tunisian gastric adenocarcinomas. Acta Histochemica 116: 2441250.

30. Ben Ayed-Guerfali D, Hassairi B, Khabir A, Sellami-Boudawara T, et al. (2014) Expression of APC, $\beta$ - cateninand E-cadherin in Tunisian patients with gastric adenocarci-noma: clinical significance. Tumour Biol 35: 1775-1783.

31. Lukyanova NY, Kulik GI, Yurchenko OV, Shatrova KM, Vorobyova LI, et al (1993) Expression of p53 and Bcl-2 proteins in epithelial ovarian carcinoma with different grade of differentiation. Experimental Oncology 22: 91-93.

32. Carlson DA, Ribeiro JM (1993) Apoptosis and disease. Lancet 341: 1251-1254 